\title{
Did I Hear you Say there is No Cure for Ulcer?
}

\section{Onyinye Prisca Anyakee*}

University of Benin, Group Pharmacy Affairs Manager at Biogenerics Nigeria Limited, Nigeria

*Corresponding Author: Olaolu Ojenike, University of Benin, Group Pharmacy Affairs Manager at Biogenerics Nigeria Limited, Nigeria.

Received: June 11, 2019; Published: October 29, 2019

DOI: 10.31080/ASPS.2019.03.0429

Prior to now, Ulcer was classified as an incurable disease due to the formation of scar (scar tissues lack the function of self-protection) at the ulcer site. Most conventional therapies manage ulcers with scarring but MEBO Gastrointestinal (GI) capsules cures ulcer without formation of scars through regenerative restoration.

A new era has been pioneered in the treatment of burns, wounds and ulcers. This technology called Moist Exposed Burn Therapy (MEBT) and Moist Exposed Burn Ointment (MEBO) achieves the in situ regenerative restoration of human organs physiologically. It was invented by Dr. Rongxiang Xu, the founder of regenerative medical technology and human body regenerative science.

Peptic ulcer is a disease characterized by the presence of open sores in the stomach or the upper part of the small intestine. Peptic ulcer could be duodenal or Gastric ulcer. Gastric Ulcer is the most common digestive disorder with a very high recurrence rate caused by the formation of the scars formed covering the hole created by the ulcer. The conventional drugs used in its management include omeprazole, cimetidine and has a high relapse rate.

\section{Mechanism of action}

Regenerative nutrients are absorbed by mucosa and glands as well as bowel wall and thus invigorate potential regenerative cells (PRCs) which in situ regenerate new cells to replace aged intestinal wall and organ cells that are procedurally renewed to younger tissues and organs.

\section{Active ingredients}

Gastrointestinal capsules popularly known as GI capsules contains Cera Flava (Beeswax), Scutellariae Radix, Sesame oil, vitamin $\mathrm{E}$ and other flavonoids helps to improve function of the gastrointestinal tract, protects the gastric mucosa, rejuvenate the skin and cellular tissue of stomach and intestine back to normal structure and function.

\section{Conclusion}

In conclusion, with the invention of regenerative restorative science ulcers would no longer be classified as refactory. The regenerative restoration science is summarized as: Wound scar formation $\rightarrow$ Wound mucosa regenerative restoration $\rightarrow$ Wound mucosa regeneration which makes ulcer relapse very slim.

\section{Volume 3 Issue 11 November 2019}

(C) All rights are reserved by Onyinye Prisca Anyakee. 